\title{
Health-related consequences of caring for dependent relatives in older adult caregivers*
}

\section{Consequências do cuidado para a saúde de idosas cuidadoras de familiares dependentes Consecuencias del cuidado para la salud de las ancianas cuidadoras de familiares dependientes}

How to cite this article:

Gomes NP, Pedreira LC, Gomes NP, Fonseca EOS, Reis LA, Santos AA. Health-related consequences of caring for dependent relatives in older adult caregivers. Rev Esc Enferm USP. 2019;53:e03446. DOI: http://dx.doi.org/10.1590/S1980-220X2018002303446

\author{
Nildete Pereira Gomes ${ }^{1}$ \\ Larissa Chaves Pedreira ${ }^{1}$ \\ Nadirlene Pereira Gomes ${ }^{1}$ \\ Elaine de Oliveira Souza Fonseca ${ }^{1}$ \\ D Luciana Araújo dos Reis ${ }^{2}$ \\ D Alice de Andrade Santos ${ }^{1}$ \\ * Extracted from the dissertation: \\ "Implicações osteomusculares vivenciadas \\ por idosos cuidadores no domicílio", \\ Universidade Federal da Bahia, 2018. \\ ${ }_{1}$ Universidade Federal da Bahia, Escola \\ de Enfermagem, Salvador, BA, Brazil. \\ ${ }^{2}$ Universidade Estadual do Sudoeste \\ da Bahia, Jequié, BA, Brazil.
}

\begin{abstract}
Objective: To know the health-related consequences of caring for dependent relatives in older adult caregivers. Method: Qualitative research carried out with older adult women who cared for family members enrolled in a federal public home care program. The identification of the older adult caregivers was done by consulting the patient's charts, and the interview took place from March to June 2017. The data were systematized based on Content Analysis. Results: Six older adult caregivers of people with impaired functional capacity participated in the study. Three categories emerged: care-related musculoskeletal pain; health problems related to the somatization of the lived feeling; and self-care deficit by virtue of caring for another. Conclusion: The study revealed the consequences of caring for dependent family members on the health of older adult caregivers. Careful management is essential to prevent and/or reduce health problems, especially regarding the musculoskeletal system.
\end{abstract}

\section{DESCRIPTORS}

Aged; Caregivers; Pain; Musculoskeletal System; Geriatric Nursing. 


\section{INTRODUCTION}

The continuing and exhausting character of caring for a person with impaired functional capacity points to the relevance of investigating its consequences for the caregiver ${ }^{(1)}$. Considering that the majority of caregivers of dependent relatives are older adult women, there is a need for studies that address the health of this group.

Research evidences a scenario of older adult women in the role of being informal caregivers for relatives with impaired functional capacity ${ }^{(2-3)}$. A national study aimed at identifying the family caregiver profile of dependent persons at home found that among the 52 participants, the majority $(96.2 \%)$ were women, and about $31 \%$ were between 61 and 80 years old ${ }^{(2)}$. In corroborating the greater number of women exercising the caregiver role, research justifies that care is a function that is socially attributed to the feminine personality, and is therefore a social construct ${ }^{(3)}$.

The task of caring for a person with impaired functional capacity implies changes in decubitus, transfers, bathing and changing diapers. A study conducted in the United States with 46 informal caregivers revealed a dense daily routine with enduring and recurring tasks, such as changing bed rests from inappropriate settings, making it difficult to accommodate the patient to adequate postures ${ }^{(4)}$. A cross-sectional study carried out with 99 home caregivers with a mean age of 65.8 years showed that caring for the other for long periods, often without any support from third parties, interferes with health ${ }^{(5)}$.

Caregiver illness is aggravated when it comes to an older adult person playing this role, since they already have alterations due to aging ${ }^{(6)}$, which together with the overload of care can further compromise their health and quality of life. Regarding the musculoskeletal system, common alterations of senescence should be considered, since bone and muscle mass loss, tendon elasticity and joint elasticity loss are present at this stage. These physiological changes tend to limit the development of activities of daily living (ADL), compromising self-care and caring for others.

The current scenario of older adult caregivers and the changes in the musculoskeletal system due to senescence warn that sensitive attention to this context is necessary in order to improve the experience of these people in caring for themselves and for another. In this sense, the following is question is proposed: What are the consequences of the care provided to the relative dependent on the health of older adult caregivers? The study aimed to know the consequences of caring for the health of dependent relatives for older adult caregivers.

\section{METHOD}

\section{StUdY TYPE}

A qualitative study linked to the main project entitled "Older adult caregivers in caring for another at home: intervening in the overload of care".

\section{SCENARIO}

The scenario consisted of the home where the older adult caregivers provided the care of relatives linked to the Best Home Program in Salvador, Bahia, Brazil. This federal public home care program aims to provide better quality home care for people with temporary or permanent difficulties. The service is performed by a multiprofessional team that is distributed in four bases in the city of Salvador, each linked to a public hospital. We chose a base linked to a large hospital, as it is considered the largest hospital specialized in trauma.

\section{SELECTION CRITERIA}

The inclusion criteria were: age of at least 60 years; be the caregiver or responsible caregiver of the dependent person, whether or not he or she is a relative; have preserved communication skills. As exclusion criterion, we considered: domicile located in a place of risk to the physical integrity of the researcher, as directed by the health team.

Fifty-three (53) patients' charts were consulted for selecting the participants. These included a form called the Social Assessment of Eligibility, which contains information regarding the people living in the home, as well as an indication of the responsible caregiver. As the registry of only one older adult was found to be a caregiver, a new consultation was carried out to identify families with older adult women among the residents of the household, and then 10 additional medical records were found. Telephone contact was made at that time to see if they acted as caregivers, and seven of the 10 performed the care, adding up to eight possible participants. Two did not agree to participate in the study, thus totaling six participants for the interview.

\section{DATA COLleCtion}

Data collection was performed between March and June 2017 through a semi-structured interview, and accompanied by a form composed of two parts: the first was for characterizing the participants, and contained questions regarding their age, relationship with the relative, care support (family, formal caregiver, domestic maid), time of care (days, months and year); and the second posed the following question: How do you perceive your health from before and after caring for your relative? The interview was recorded and transcribed in its entirety with the consent of the older adult caregivers. The participants were represented by flower names to ensure anonymity, since they convey both delicacy and vitality, being essential adjectives for the caregivers of dependent people.

\section{DATA ANALYSIS AND PROCESSING}

The data organization process was performed based on the Content Analysis proposed by Bardin ${ }^{(7)}$. This is a set of communication analysis techniques which uses systematic procedures and objectives to describe the contents of the messages, thereby allowing inference of knowledge regarding the production conditions. In this sense, three stages were followed: in the first (the pre-analysis), the research corpus and systematization of ideas on the theme were constituted focusing on the research question; in the second, the material was explored to categorize the data in order to reach the registration and context units, favoring construction of the analysis categories. The rules of completeness, 
representativeness, homogeneity and pertinence based on the research corpus and research question were observed herein. Finally, the results were treated with interpretation and inference in the third stage, considering mutual exclusion, homogeneity, pertinence, objectivity, fidelity and productivity, with a production of consistent results which could bring new knowledge ${ }^{(7)}$. In this way, it was possible to form three thematic categories representative of the consequences of care provided by older adult women to family members with impaired functional capacity.

\section{ETHICAL ASPECTS}

The study respected the ethical principles of Resolution No. 466/2012 of the National Health Council and was approved by the Research Ethics Committee of the Nursing School of the Universidade Federal da Bahia on 10/05/2016, under Opinion no. 1.762.501.

\section{RESULTS}

Six women caregivers aged between 60 and 79 years participated in the study, following the world trend of the majority being female. One caregiver lived near their dependent's home and five lived in the same household, two had previously lived with their relative, two had taken their relative into their homes, and one who lived in another country returned to take care of their relative.

Regarding the familial relationship with the person provided cared for, one was a caregiver of their grandson who was lucid and collaborative, and despite being in a wheelchair, he performed his tasks alone, only depending on his grandmother to cook and push the shower chair to the bathroom; two were caregivers for their children, they did not make contact, they were restricted to the bed and totally dependent; and three were caregivers for their mothers, who also did not interact, were restricted to the bed and totally dependent.

The care time for family members ranged from 1 year and 5 months to 6 years, and care was provided every day of the week. In relation to support in the care process, four had the support of a family member; three had formal caregivers and/or domestic employees; and one did not have any support.

Among the six caregivers interviewed, only one stated that they had no complaints regarding their musculoskeletal system. She attended health service regularly, participated in a cohabitation group for older adults for 17 years and did yoga and dance classes. Her relationship was being the grandmother and she had help from a daughter, the grandchild's mother, which allowed her to carry out most of her activities of daily living.

The reports by the older adult caregivers about consequences related to their musculoskeletal system are affected by the musculoskeletal pain caused by care, health problems related to the somatization of the lived feeling and the deficit in self-care due to caring for the other. These implications were organized in the following representative categories:

\section{Care-related musculosikeletal pain}

The appearance and/or aggravation of musculoskeletal pain related to the daily mobilization of caring for people were reported in the testimonies.

(...) I feel pain when I lift him to put him in a higher position of the bed. (...) I already had arthrosis in my knee, but after I came to take care of him, it hurts a lot. (...) it is difficult to crouch, go up and down stairs. I feel insecure to go out alone (Rose, 63, 6-year caregiver of her 31-year-old son, diagnosed with a severe head injury due to an automobile accident).

At the beginning of caring for my mother, I felt pain in my spine as I lifted her from the wheelchair or from the bed. The pain became unbearable when I was carrying her daily, but when the physiotherapist taught me the correct posture to move her, I did not feel any more pain (Jasmine, 72 years old, caregiver of her 98-year-old mother for 3 years).

\section{HeAlth problems related to the somatization of the LIVED FEELING}

The testimonies show that exhaustive daily life, constant concern and alertness associated with the need to care for the family member lead to situations of emotional stress on the part of the older adult caregivers. These tend to present psychosomatic symptoms because of the experience, which in turn contribute to musculoskeletal disorders and other health problems.

I had no time to sleep because I needed to take care of her. I feel exhausted most of the time! All this is a reflection of what I have lived! (...) sometimes I feel pain from my hair to my feet, I feel so tired that even when I had won money to go to the movies, I preferred to do a massage and acupuncture session instead (Orchid, 63 years old, caregiver for 4 years of her 91-year-old mother).

If she calls or grunts, I rush out of my room to see her. Sometimes I feel neurotic. I need a psychologist. (...) my body no longer seems to be reacting (Tulip, 60 years old, caregiver of her 86-year-old mother for 1 year and 5 months).

\section{DEFICIT IN SELF-CARE DUE TO CARING FOR ANOTHER}

Through the testimonies it is observed that caregivers neglect self-care due to their involvement in the various care activities with their family member, exclusively and integrally dedicating themselves to it. There is evidence of a lack of prevention measures such as regular physical activities and health follow-up which contribute to the onset of musculoskeletal pain and self-medicating.

I'm feeling pain in my body all the time, I even think it's $f$ bromyalgia. (...) I never stopped doing anything because of the pain: I took medicine and I did it! (...) I'm taking analgesics, anti-inflammatories and antibiotics, often without prescription. (...) I don't do any medical monitoring because I have dedicated myself exclusively to it. (...) I've only gone to the emergency when something serious happens to me. (...) I don't do physical activities (Orchid, 63 years old, caregiver of her 91-year-old mother for 4 years). 
I always liked to take care of myself, but now my time is just for him. (...) I stopped walking and exercising. I've not been to a medical consultation for more than a year (Sunflower, 73 years old, caregiver of her 49-year-old son for 6 years and 6 months).

\section{DISCUSSION}

The study indicates that the activities demanded for the care of dependent people compromise the musculoskeletal health of caregivers, characterized by muscular and joint pain. These implications, according to the participants, are due to the overload of weight in their care tasks, among other reasons. An American study corroborates the interference of daily care activities for dependent people in aggravating musculoskeletal discomfort ${ }^{(4)}$.

This fact is aggravated by the care actions of people with impaired functional capacity, which are characterized as being repetitive, long-lasting and/or requiring a long period in a static position. The objective of this study was to learn about the factors that lead to musculoskeletal pain in caregivers, revealing a static and time-consuming relationship with the daily routine of the women, such as feeding patients who hooked up to probes ${ }^{(3)}$.

It is important to emphasize that this musculoskeletal illness can be aggravated since the caregivers perform the tasks during the seven days of the week and for many years, such as in the case of Rose who is 63 years old, and has dedicated 6 years entirely to caring for her child with a diagnosis of cranioencephaly trauma due to an automobile accident, being tracheostomized and totally dependent. The intense work by the caregiver of bedridden people was also pointed out as a factor which predisposes them to developing musculoskeletal lesions in a study that aimed to identify the occurrence of low back pain in nursing professionals ${ }^{(8)}$.

Given the interface between full-time and long-term care with continuous efforts and the onset of musculoskeletal pain in the person promoting care, it is important to note such implications in the context of the older adult caregiver. This is because the aging process (as already pointed out) triggers physiological changes which are characteristic of senescence regarding muscle mass and strength. It should be noted that bone mineral density which decreases with advancing age is more intense in females, especially after menopause when there is a sudden reduction in estrogen levels, a hormone responsible for calcium replacement in the bones, leaving them more fragile and prone to fractures ${ }^{(9)}$. Therefore, it can be seen that the female gender in this osteomuscular physiological wear situation is more susceptible to the injury.

Given this context, it is important to emphasize female hegemony in informal care, representing $84 \%$ of this group, being mostly daughters and wives ${ }^{(10-12)}$. With regard to familial relationship, this study had three daughters, two mothers and a grandmother, attesting that the responsibility for care still remains as an attribute of the feminine universe. Thus, it can be inferred that the caregiver role socioculturally attributed to women and associated with the physiological process of aging, places older adults as a group at greater risk for musculoskeletal disorders. Therefore, care actions should be prioritized with the inclusion of preventive-educational activities.

As a primary caregiver, daily tasks are predisposed to the interviewed older adult caregivers for the onset of pain, bursitis, low back pain and arthrosis. The upper limbs, knees, cervical spine and lumbar spine are the most affected regions. Research with 20 caregivers aged between 25 and 60 years showed the most frequent osteomuscular problems in the lumbar region, lower limbs, shoulders, cervical region, arms and dorsal region ${ }^{(13)}$.

It should be noted that the musculoskeletal impairments resulting from caring for the dependent person add to the restlessness experienced by the family member's well-being. The testimonies in this study revealed that the daily provided care is permeated by tension resulting from the continuous and intense preoccupation with the dependent entity, expressed by the state of alertness. It is important to emphasize that caregivers are more likely to develop stress ${ }^{(14)}$. The fact of being continually attentive to every need that the cared for patient presents in the day-to-day, to the undefined amount of time for the necessity of this care, to the care logistics like provision and prediction of materials and food, in addition to its costs, tends to bring visible reactions on the quality of life of these caregivers, such as triggering excessive stress, which is reflected in problems expressed in the physical body.

A study carried out in Germany observed a certain psychological burden in family caregivers of patients with advanced cancer during palliative care, evidenced by feelings of distress, sadness and anxiety reported by these caregiv$\mathrm{ers}^{(12)}$. Therefore, it is noticed that the caring for the relative raises emotional problems in the caregivers, which are somatized and expressed in the physical body. Psychosomatic manifestations are considered symbolic forms of communication with the body, and consist of physical symptoms triggered by emotional distress. A study carried out with patients and family caregivers in Malaysia being an average age of 47 years old confirms that the exclusive care of a dependent patient can lead the caregiver to present anxiety and depression, which end up compromising their emotional and physical health ${ }^{(11)}$.

Given this context, it is necessary to have a sensitive look at the subjective questions related to the somatization process, because in this sense by signaling the connection of the body with the mind, studies admit an expression of psychological problems in the body ${ }^{(8,15)}$. The interviewed older adult women also demonstrated an understanding that their illness is a reflection of what they have experienced in the process of caring for their dependent family member to the detriment of themselves. For them, somatization of tension and stress related to the care process was associated with sudden and involuntary weight loss; to syndromes resulting from tensional muscular contraction, such as lumbar and cervical pain; to tachycardia and asthenia, expressed by reports of discouragement, physical exhaustion and feeling of continuous exhaustion. 
Specifically regarding the sensation of physical fatigue related to caring for dependent people, the somatization process was also perceived in a study that associated quality of life with caregiver overload, revealing excessive stress as a trigger of mental fatigue, deconcentration, apathy, anxiety, depression and muscle fatigue ${ }^{(16)}$.

Whether is triggered by the arduous tasks of care or is related to the somatization of the lived experiences, musculoskeletal syndrome compromises daily activities in older adult caregivers. Three of the six interviewees mentioned limiting movements, such as crouching and going up/down stairs, which limited their mobility and brought insecurity even to go out alone. Thus, some physical actions are limited due to the difficulty of movement, also restricting social interaction. Pain complaints in the lumbar region were also pointed out by authors as limiting movements, hindering the performance of tasks and compromising the quality of life of the investigated subjects ${ }^{(17)}$.

This study also evidences the neglect of self-care on the part of the interviewees who declared themselves to be so involved in the intense, exhaustive care and emotional tension that they could not reserve time for themselves, sometimes becoming ill. Difficulty to dedicate themselves to their own health was also identified in a study that evidenced illness in caregivers of over 60 years of age who provided care to people with impaired functional capacity ${ }^{(16)}$.

In this context, caregivers reported practicing self-medication for analgesics, anti-inflammatories and antibiotics. This situation was also observed in another study with 92 caregivers aged 58 to 97 years, who reported overload from caring for people at home and using medications ${ }^{(18)}$. It is important to emphasize that the indiscriminate use of medications by older adults, not necessarily caregivers, has been a practice unveiled in the literature, mainly for pain relief. Self-medication among older adults is frequent and was demonstrated in a cross-sectional study with 272 older adults with a prevalence of $83 \%{ }^{(19)}$. Inadequate consumption of drugs is a worrying situation and may negatively reflect the health of these caregivers, mainly due to their adverse effects.

In the testimonies, it was also identified that caregivers do not regularly seek out health services due to the delayed care in the Unified Health System, which is aggravated by their unavailability for self-care. A cross-sectional study of 315 informal caregivers of older adults people found that the majority felt the need for regular medical care at home, precisely because they did not have time to travel to the service ${ }^{(11)}$.

Strategies are necessary to enable caregiver access to medical centers given the inherent tasks of caring for others, the tension of caregivers to be with their families and the delay in care in the health services. It is worth noting that although there are services with a multiprofessional team responsible for providing caring to dependent patients, these are not intended for a person who is a caregiver, which represents a paradox in the health system. This is because a caregiver who becomes ill will not be able to maintain the care quality. In view of the aging in the Brazilian population, this situation is even more delicate, since the growth in the indices of older adult caregivers for other older adults ${ }^{(20)}$, especially female caregivers, is notorious. Therefore, it is essential to enable care spaces for the people who are performing the caregiver role.

Another neglect observed regarding self- healthcare was the fact that older adult women did not perform physical activities. In their testimonies, the caregivers pointed out the need to be constantly present with their relatives, expressing their carelessness with themselves because of the constant care being provided to their dependent family member. A study carried out with 325 older adult caregivers aged 60 years or older showed that the majority had physical functional limitations, as well as fatigue and lack of energy, in addition to not performing physical activity, constituting an event that interfered in their quality of life ${ }^{(21)}$. It is understood that sedentarism and/or absence of activities compromises the physical condition of the caregivers, leading to increase their musculoskeletal pain. Regarding this, it should be considered that the overload on physical and emotional spheres contributes to neglect of self-care and consequent impairment to caregivers' health ${ }^{(22)}$.

In the present study, caregivers between the ages of 60 and 79 pointed out that it is imperative to be with their dependent under their care. It is understood that this attitude can symbolize an affective demand of the caregiver herself, which is perceived as essential in this process. This ratifies research developed in Singapore which also pointed to the belief of caregivers as having a need to be continuously present in the life of the person cared for, so that compulsive feelings of constant availability even make them give up vacation travel $^{(23)}$.

The perception that their health is unsatisfactory is seen in a cross-sectional study conducted in Malaysia, in which family caregivers aged over 18 years of stroke survivors selfrated their health as "poor", and were more vulnerable to chronic diseases such as diabetes mellitus, in addition to presenting depressive symptoms and back pain ${ }^{(11)}$.

In view of the musculoskeletal problems presented by caregivers and the context of self-care neglect, it is important to think about health promotion strategies which meet the physical, psychological and social demands of these people. Emphasis in this process is placed on the relevance of nursing practice in raising awareness among professionals to better assist patients' needs $s^{(24)}$.

Strategies should also prioritize actions to promote health, focusing on preventing disorders due to the exhaustive tasks and intense concern of caring for the family member. Regarding musculoskeletal problems, it should be noted that acupuncture and massage are alternatives which are sought as methods to attenuate the manifested symptomatology. According to research on Complementary and Alternative Medicine Services in the US Military Health System, acupuncture and chiropractic methods are commonly applied in cases of pain and stress management ${ }^{(25)}$. Another international study also highlighted the effect of massage for relief of physical and psychological symptoms in caregivers of cancer patients who reported fatigue due to care actions ${ }^{(26)}$. 
Also in the field of health promotion, actions aimed at family reorganization are necessary in order to divide tasks and responsibilities, preventing overload in one person. In this way, caregivers' musculoskeletal diseases can be reduced, since the tasks, as well as the concerns, will be better distributed, favoring availability of time for self-care.

Another strategy for preventing musculoskeletal problems and their implications on the health of family caregivers (who represents a collaborator of direct care to the dependent person) is education for adequate mobilization. A national study argues that musculoskeletal pain may be due to muscular effort required and improper handling epi$\operatorname{sodes}^{(27)}$; a reality that reflects the care given to the interviewed older adult women.

Improper body positioning while performing procedures may be related to a lack of knowledge about ergonomics. Research carried out in Iran also points out the importance of ergonomic posture to perform activities, since postureconscious caregivers were less predisposed to musculoskeletal pain when compared to those who did not have this awareness ${ }^{(28)}$. In the Brazilian scenario, caregivers are also not in their perfect condition to provide care, presenting physicalemotional exhaustion. A study of 40 informal caregivers with a mean age of 55 years found that the majority, despite being the main caregiver, had never performed any training to exercise this role ${ }^{(15)}$, which may have led to incorrect postures for performing care maneuvers.

Research with health professionals indicates that by not receiving guidelines on ergonomic principles, caregivers are more susceptible to inadequate postures in the care process, and consequently to developing work-related low back pain. The research also points out that guidelines and training should be offered on ergonomic knowledge in order to favor changes in habits for performing procedures with greater body awareness, with the purpose of preventing injuries ${ }^{(8)}$.

It can be seen that ergonomic guidelines performed by trained professionals can be an important method to prevent musculoskeletal injuries caused in older adult caregivers of bedridden patients ${ }^{(29)}$. In this study, a caregiver reported improvement in pain after an intervention by a physiotherapist, whose developed techniques favor pain control and improvement in functional status.

It is important to emphasize that physiotherapy professionals as well as those of physical education are the most qualified to carry out preventive ergonomic activities, since the anatomical, physiological and biomechanical knowledge of the human body is included in their academic curricula ${ }^{(29)}$. As revealed by a study in Iran, another tactic for preventing and reducing musculoskeletal pain consists of performing muscle stretching before and after care activities ${ }^{(28)}$.
It is possible to perceive that health professionals are noteworthy in the process of caring for caregivers of dependent people, as they need attention for preventing and/or reducing their musculoskeletal health as a result of daily care tasks. Considering that caring for a dependent patient demands good health by the caregiver, especially in the case of an older adult, the multiprofessional health team must carry out a holistic evaluation with the aim to prevent and reduce disabilities and stimulate self-care ${ }^{(30)}$.

One limitation of the study was the delimitation of resident caregivers of a certain region of the city of Salvador, in the Brazilian Northeast. The fact that this region encompasses neighborhoods whose residents have higher purchasing power who can afford formal caregivers and/or domestic employees means that musculoskeletal implications may be more intensely present in caregivers in poorer regions. This gap in the study directs us to invest research in this sense.

\section{CONCLUSION}

The study revealed that providing care for a dependent with impairment in functional capacity results in muscular and articular pain, being directly related to the repetitive and enduring tasks and/or in response to somatizing the suffering resulting from extreme concern with the relative. It is also noticed that the older adult caregivers are more vulnerable to neglecting their self-care due to the attention they dedicate to their families. This is because in providing care for the other they give up taking care of themselves, so that they use self-medication for symptomatic relief, they do not seek out health services and they do not perform physical activities.

This study offers support for reflections about the performance of work by the multiprofessional team in the health care of the home caregiver, especially in the scenario of an aging population, in which many caregivers are older adults. In this sense, the study contributes to highlight the need for educational actions to sensitize older adults caregivers about their greater susceptibility to changes in their musculoskeletal systems due to senescence and from caring for a dependent person, as well as to educate them for performing self-care, which is essential to continue to carry out the tasks demanded by family members.

Given this context, management which excels in caring for the caregiver is essential, making relevant a more intense bond with the nursing team, given their action throughout the care process, and especially in health education. Physical therapy can also participate with guidelines on ergonomics, preventing and/or reducing musculoskeletal problems arising from providing care.

\section{RESUMO}

Objetivo: Conhecer as consequências do cuidado para a saúde de idosas cuidadoras de familiares dependentes. Método: Pesquisa qualitativa, realizada com idosas que prestavam cuidado de familiares cadastrados em um programa público federal de atenção domiciliar. A identificação das idosas cuidadoras se deu por meio de consulta aos prontuários da pessoa dependente, e a entrevista ocorreu no período de março a junho de 2017. Os dados foram sistematizados com base na Análise de Conteúdo. Resultados: Participaram do estudo seis idosas cuidadoras de pessoas com capacidade funcional comprometida. Emergiram três categorias: dor osteomuscular relacionada ao cuidado; problemas de saúde relacionados à somatização do sentimento vivido; e deficit do autocuidado em virtude 
do cuidado com o outro. Conclusão: $O$ estudo revelou as consequências de cuidar de familiares dependentes para a saúde de idosas cuidadoras, sendo essencial uma gestão que prime pelo cuidado do cuidador no sentido de prevenir e/ou reduzir problemas de saúde, principalmente no tocante ao sistema osteomuscular.

\section{DESCRITORES}

Idoso; Cuidadores; Dor; Sistema Musculoesquelético; Enfermagem Geriátrica.

\section{RESUMEN}

Objetivo: Conocer las consecuencias del cuidado para la salud de las ancianas cuidadoras de familiares dependientes. Método: Investigación cualitativa, realizada con ancianas que prestaban cuidado a familiares inscritos en un programa público federal de atención domiciliaria. La identificación de las ancianas se dio mediante consulta a las fichas de la persona dependiente, y la entrevista ocurrió en el período de marzo a junio de 2017. Los datos fueron sistematizados con base en el Análisis de Contenido. Resultados: Participaron en el estudio seis ancianas cuidadoras de personas con capacidad funcional comprometida. Surgieron tres categorías: dolor osteomuscular relacionado con el cuidado; problemas de salud relacionados con la somatización del sentimiento vivido; y déficit del autocuidado en virtud del cuidado con el otro. Conclusión: El estudio reveló las consecuencias de cuidar a familiares dependientes para la salud de ancianas cuidadoras, siendo esencial una gestión en la que prime el cuidado del cuidador a fin de prevenir y/o reducir problemas sanitarios, especialmente en lo concerniente al sistema osteomuscular.

\section{DESCRIPTORES}

Anciano; Cuidadores; Dolor; Sistema Musculoesquelético; Enfermería Geriátrica.

\section{REFERENCES}

1. Delalibera M, Barbosa A, Leal I. Circunstâncias e consequências do cuidar caracterização do cuidador familiar em cuidados paliativos. Ciênc Saúde Coletiva [Internet]. 2018 [citado 2018 jun. 20;23(4):1105-17. Disponível em: : http://www.scielo.br/scielo.php?script=sci_ arttext\&pid=S1413-81232018000401105\&lng=pt

2. Loureiro LSN, Fernandes MGM. Profile of the family caregiver of dependent elderly in home living . Rev Pesq Cuid Fundam Online [Internet]. 2015 [cited 2017 Dec 24];7(5):145-54. Available from: http://seer.unirio.br/index.php/cuidadofundamental/article/view/5884

3. Suzuki K, Tamakoshi K, Sakakibara H. Caregiving activities closely associated with the development of low-back pain among female family caregivers. J Clin Nurs. 2016;25(15-16):2156-67. DOI: 10.1111/jocn.13167

4. Darragh AR, Lavender SA, Tanner J, Vogel K, Campo M. Musculoskeletal discomfort, physical demand and caregiving activities in informal caregivers. J Appl Gerontol. 2015; 34(6):734-60. DOI:10.1177/0733464813496464

5. Brigola AG, Luchesi BM, Rossetti ES, Mioshi E, Inouye K, Pavarini SCI. Health profile of family caregivers of the elderly and its association with variables of car: a rural study. Rev Bras Geriatr Gerontol. 2017;20(3):410-22.

6. Andrade KRC, Silva MT, Galvão TF, Pereira MG. Functional disability of adults in Brazil: prevalence and associated factors. Rev Saúde Pública [Internet]. 2015 [cited 2018 May 25]; 49: 89. Available from: http://www.scielo.br/scielo.php?script=sci_arttext\&pid $=$ S0034-89102015000100268

7. Bardin L. Análise de conteúdo. Lisboa: Edições 70; 2016.

8. Freire LA, Soares TCN, Torres VPS. Influência da ergonomia na biomecânica de profissionais de enfermagem no ambiente hospitalar. Persp Online Biol Saúde [Internet]. 2017 [cited 2017 dez. 13];7(24):72-80. Disponível em: http://seer.perspectivasonline.com.br/index.php/ biologicas_e_saude/article/view/1149/929

9. Dawson A, Dennison E. Measuring the musculoskeletal aging phenotype. Maturitas. 2016;93:13-7. DOI: http://dx.doi.org/doi:10.1016/j. maturitas.2016.04.014

10. Alshammari SA, Alzahrani AA, Alabduljabbar KA, Aldaghri AA, Alhusainy YA, Khan MA, et al. The burden perceived by informal caregivers of the elderly in Saudi Arabia. J Family Community Med. 2017;2 (3):145-50. DOI: 10.4103/jfcm.JFCM_117_16

11. Wan-Fei K, Syed Hassan ST, Munn Sann L, Fadhilah Ismail SI, Abdul Raman R, Ibrahim F. Depression, anxiety and quality of life in stroke survivors and their family caregivers: a pilot study using an actor/partner interdependence model. Electron Physician [Internet]. 2017 [cited 2017 Dec 13];9(8):4924-33. Available from: https://www.ncbi.nlm.nih.gov/pmc/articles/PMC5614274/

12. Ullrich A, Ascherfeld L, Marx G, Bokemeyer C, Bergelt C, Oechsle K. Quality of life, psychological burden, needs, and satisfaction during specialized inpatient palliative care in family caregivers of advanced cancer patients. BMC Palliat Care [Internet]. 2017 [cited 2017 Nov 13];16:31 . Available from: https://www.ncbi.nlm.nih.gov/pmc/articles/PMC5424283/

13. Arruda MF, Peres MR, Brumati Junior C. Index of musculoskeletal injuries and their correlation with postural disorders in elderly caregivers. Rev Saúde Pesq [Internet]. 2015 [citado 2017 dez. 13];8(1):105-12. Disponível em: http://periodicos.unicesumar.edu.br/index.php/ saudpesq/article/view/3990/2560

14. Souza LR, Hanus JS, Dela Libera LB, Silva VM, Mangilli EM, Simões PW, et al. Sobrecarga no cuidado, estresse e impacto na qualidade de vida de cuidadores domiciliares assistidos na atenção básica. Cad Saúde Coletiva [Internet]. 2015 [citado 2017 dez. 13];23(2):140-9. Available from: http://www.scielo.br/scielo.php?script=sci_arttext\&pid=S1414-462X2015000200140\&lng=pt\&tlng=pt

15. Reis LA, Santos KT, Gomes NP, Reis LA. Determinantes da sobrecarga emocional e desconforto em cuidadores de idosos. Rev Enferm Contemp. 2016;5(1):59-67.

16. Costa TF, Costa KNFM, Fernandes MGM, Martins KP, Brito SS. Quality of life of caregivers for patients of cerebrovascular accidents: association of (socio-demographic) characteristics and burden. Rev Esc Enferm USP [Internet]. 2015 [cited 2017 Nov 23];49(2):245-52. Available from: http://www.scielo.br/scielo.php?script=sci_arttext\&pid=S0080-62342015000200245

17. Lopes TM, Casa Júnior AJ. Avaliação da capacidade funcional e da qualidade de vida de indivíduos com dor lombar inespecífica. Estudos Vida Saúde [Internet]. 2014 [citado 2017 dez. 21];41(2):223-35. Disponível em: http://seer.pucgoias.edu.br/index.php/estudos/article/ view/3380/1966 
18. Leite BS, Camacho ACLF, Joaquim FL, Gurgel JL, Lima TR, Queiroz RS. The vulnerability of elderly caregivers with dementia: a crosssectional descriptive study. Rev Bras Enferm [Internet]. 2017 [cited 2017 Dec 20];70(4):714-20. Available from: http://www.scielo.br/pdf/ reben/v70n4/0034-7167-reben-70-04-0682.pdf

19. Jafari F, Khatony A, Rahmani E. Prevalence of self-medication among the elderly in Kermanshah-Iran. Glob J Health Sci [Internet]. 2015 [cited 2017 Dec 20];7(2):360-5. Available from: https://www.ncbi.nlm.nih.gov/pmc/articles/PMC4796481/

20. Santos-Orlandi AA, Brito TRP, Ottaviani AC, Rossetti ES, Zazzetta MS, Gratão ACM, et al. Profile of older adults caring for other older adults in contexts of high social vulnerability. Esc Anna Nery [Internet]. 2017 [cited 2017 Dec. 20];21(1): e20170013. Available from: http://www.scielo.br/scielo.php?pid=S1414-81452017000100213\&script=sci_arttext\&tlng=en

21. Faronbi JO, Olaogun AA. The influence of caregivers' burden on the quality of life for caregivers of older adults with chronic illness in Nigeria. Int Psychogeriatrics. 2017;29(7):1085-93. DOI: https://doi.org/10.1017/S1041610216002295

22. Olanda KKR, Passos XS, Dias CS. Perfil das morbidades dos cuidadores informais de idosos com Alzheimer. J Health Sci Inst [Internet]. 2015 [citado 2017 nov. 21];33 (1):83-8. Disponível em: https://www.unip.br/presencial/comunicacao/publicacoes/ics/edicoes/2015/01_jan-mar/ V33_n1_2015_p83a88.pdf

23. Tan SB, Williams AF, Morris ME. Experiences of caregivers of people with Parkinson's disease in Singapore: a qualitative analysis. J Clin Nurs. 2012;21(15-16):2235-46. DOI: 10.1111/j.1365-2702.2012.04146.x

24. Primeau C, Paterson C, Nabi G. A qualitative study exploring models of supportive care in men and their partners/caregivers affected by metastatic prostate cancer. Oncol Nurs Forum. 2017;44 (6): E241-9. DOI: 10.1188/17.ONF.E241-E249

25. Herman PM, Sorbero ME, Sims-Columbia AC. Complementary and alternative medicine services in the Military Health System. J Altern Complement Med. [Internet]. 2017 [cited 2017 Nov. 29];33(11):837-43. DOI: 10.1089/acm.2017.0236

26. Lopez G, Liu W, Milbury K, Spelman A, Wei Q, Bruera E, et al. The effects of oncology massage on symptom self-report for cancer patients and their caregivers. Support Care Cancer. Support Care Cancer. 2017;25(12):3645-50. DOI: 10.1007/s00520-017-3784-7

27. Guerra HS, Almeida NAM,Souza MR, Minamisava R. A sobrecarga do cuidador domiciliar. Rev Bras Promoção Saúde. 2017 [citado 2017 nov. 21];30(2):179-86. Disponível em: http://periodicos.unifor.br/RBPS/article/view/6043

28. Shirzaei M, Mirzaei R, Khaje-Alizade A, Mohammadi M. Evaluation of ergonomic factors and postures that cause muscle pains in dentistry students' bodies. J Clin Exp Dent [Internet]. 2015[cited 2017 Nov 19];7(3):e414-8. Available from: https://www.ncbi.nlm.nih.gov/pmc/ articles/PMC4554244/

29. Silva FA, Duarte HKOS, Raimundo RJS. Estudo sobre automedicação no uso de antiinflamatórios não esteroídes na cidade de Valparaíso de Goiás. Rev Saúde Desenvolv [Internet]. 2016 [citado 2017 nov. 21];9(5):142-53. Disponível em:https://www.uninter.com/revistasaude/ index.php/saudeDesenvolvimento/article/view/537/314

30. Morais D, Terassi M, Inouye K, Luchesi BM, Pavarini SCl. Chronic pain in elderly caregivers at diff erent levels of frailty. Rev Gaúcha Enferm [Internet]. 2016 [cited 2017 Nov 21];37(4):e60700. Available from: http://www.scielo.br/pdf/rgenf/v37n4/en_0102-6933rgenf-1983-144720160460700.pdf 


\section{Erratum - Health-related consequences of caring for dependent relatives in older adult caregivers}

In the article "Health-related consequences of caring for dependent relatives in older adult caregivers", DOI: http:// dx.doi.org/10.1590/s1980-220x2018002303446, published by the journal "Revista da Escola de Enfermagem da USP", Volume 53 of 2019, elocation e03446, on page 1:

Where was written:

Approved: 09/20/2019

Now read:

Approved: 09/20/2018 